\title{
The influence of the freshwater environment and the biological characteristics of Atlantic salmon smolts on their subsequent marine survival
}

\author{
Ian C. Russell ${ }^{1 *}$, Miran W. Aprahamian², Jon Barry', lan C. Davidson ${ }^{3}$, Peder Fiske ${ }^{4}$,
} Anton T. Ibbotson ${ }^{5}$, Richard J. Kennedy ${ }^{6}$, Julian C. Maclean ${ }^{7}$, Andrew Moore ${ }^{1}$, Jaime Otero ${ }^{8}$, Ted (E. C. E.) Potter ${ }^{1}$, and Christopher D. Todd ${ }^{9}$

${ }^{1}$ Cefas, Pakefield Road, Lowestoft, Suffolk NR33 OHT, UK

${ }^{2}$ Environment Agency, Richard Fairclough House, Knutsford Road, Warrington WA4 1HG, UK

${ }^{3}$ Environment Agency, Chester Road, Buckley, Flintshire CH7 3AJ, UK

${ }^{4}$ Norwegian Institute for Nature Research, PO Box 5685, Sluppen, Trondheim 7485, Norway

${ }^{5}$ Game and Wildlife Conservation Trust, Salmon and Trout Research Centre, The River Laboratory, East Stoke, Wareham, Dorset BH20 6BB, UK

${ }^{6}$ River Bush Salmon Station, 21 Church Street, Bushmills, Co Antrim BT57 8QJ, UK

${ }^{7}$ Marine Scotland Science, Freshwater Laboratory, Field Station, Inchbraoch House, South Quay, Ferryden, Montrose, Angus DD10 9SL, UK

${ }^{8}$ Centre for Ecological and Evolutionary Synthesis (CEES), University of Oslo, PO Box 1066, Oslo N-0316, Norway

${ }^{9}$ Scottish Oceans Institute, University of St Andrews, St Andrews, Fife KY16 8LB, UK

*Corresponding Author: tel: +44 1502 524330; fax: +44 1502 513865; e-mail: ian.russell@cefas.co.uk.

Russell, I. C., Aprahamian, M. W., Barry, J., Davidson, I. C., Fiske, P., Ibbotson, A. T., Kennedy, R. J., Maclean, J. C., Moore, A., Otero, J., Potter, E. C. E., and Todd, C. D. The influence of the freshwater environment and the biological characteristics of Atlantic salmon smolts on their subsequent marine survival. - ICES Journal of Marine Science, doi:10.1093/icesjms/fsr208.

Received 31 August 2011; accepted 9 November 2011.

Atlantic salmon have declined markedly in the past 20-30 years throughout their range. Much of the focus for this decline has been on increased mortality during the marine phase of the life cycle. However, marine mortality does not operate independently of factors acting in freshwater and the biological characteristics of smolts migrating to sea. Over recent decades, juvenile salmon in many rivers have grown faster and migrated to sea at a younger age, so have been typically smaller than earlier. This has shortened the generation time for many individuals and may dampen the impact of increased marine mortality, assuming that expected higher in-river survival prior to smolting is not outweighed by increased mortality of smaller smolts at sea. Over the same period, smolt run-timing across the geographic range has been earlier, at an average rate of almost $3 \mathrm{~d}$ per decade. This has given rise to growing concerns about smolts potentially missing the optimum environmental migration "window", the timing of which may also be changing. Contaminants and other factors operating in freshwater also impact smolt quality with adverse consequences for their physiological readiness for life at sea. Given that managers have very limited ability to influence the broad scale factors limiting salmon survival at sea, it is vital that freshwater habitats are managed to both maximize the smolt output and to minimize the impact of factors acting in freshwater that may compromise salmon once they migrate to sea.

Keywords: Atlantic salmon, biological characteristics, climate change, freshwater, marine survival, smolts.

\section{Introduction}

Over the past 20-30 years, there has been a marked decline in the abundance of Atlantic salmon throughout most of the species' distributional range and, in some rivers, populations have been lost (ICES, 2011). The coherence observed in the declining patterns of adult recruitment over large geographic areas suggests that recent changes in mortality have been dominated by factors operating in the marine environment (Friedland, 1998). The relative impact of the various biotic and abiotic factors affecting salmon survival at sea are poorly understood (Friedland, 1998), but it is generally accepted that the main mortality events take place during the first year of sea life (Hansen and Quinn, 1998; Potter and Crozier, 2000; Friedland et al., 2005, 2009). Further, marine mortality is generally considered to be 
density-independent, because salmon abundance is not thought to be constrained by competition for food or space in the North Atlantic (Jonsson and Jonsson, 2004).

Populations at the southern edge of their historical distribution have suffered the greatest decline (Parrish et al., 1998; Jonsson and Jonsson, 2009), coincident with a variety of climatic and environmental changes (IPCC, 2007). Such factors would be expected to have most marked effects at the edge of the species' range, but these are often also the areas with higher human population density, where potential impacts on the freshwater environment may also be greater (Parrish et al., 1998).

Atlantic salmon occupy freshwater, estuarine, and marine habitats during their life and the factors contributing to their mortality in these environments do not operate independently. Conditions experienced in freshwater can affect the survival of emigrating smolts (e.g. Jutila et al., 2006), and marine conditions may subsequently modify the spawning success of fish in freshwater (e.g. Todd et al., 2008). It has been suggested that the influence of freshwater factors may have been understated in the observed decline in the species (Crozier and Kennedy, 2003) and that the changing conditions in freshwater, rather than at sea, may be the more important factor in regulating the future distribution and viability of the species (Friedland et al., 2009).

Within the freshwater environment, climate change is a particular concern (e.g. Todd et al., 2011), because temperature increases over land are expected to exceed those over the surface of the oceans (IPCC, 2007). Higher temperatures and increased climate variability are predicted to affect all components of the global freshwater system (IPCC, 2007), with the greatest increases at northern latitudes. Precipitation is expected to increase globally, with "wet" areas typically becoming even wetter, but with increased variability such that the risk of both floods and droughts will increase. Where much winter precipitation currently falls as snow, marked seasonal changes are predicted in peak river flow, with a shift from spring to winter caused by early snow melt, and lower flows in summer and autumn (Bates et al., 2008). Higher water temperatures and variations in run-off are also expected to produce adverse changes in water quality (IPCC, 2007).

Jonsson and Jonsson (2009) reviewed climate change impacts and suggested that there is reason to expect a northward shift in the thermal niche of anadromous salmonids, with decreased production and population extinction in the southern part of the distribution areas. Effects on Atlantic salmon are expected to include earlier smolt migration, later spawning, younger ages at smolting and attainment of sexual maturity, and increased mortality. However, photoperiod also plays a crucial role in the timing of critical life-stage events such as smoltification, juvenile emigration, and adult spawning. Therefore, whereas temperature at a particular location may change, photoperiod will not. Hence, a key issue may be how rapidly a population will evolve genetically in response to potentially conflicting environmental signals (Naish and Hard, 2008).

The focus of this paper is on the role that the freshwater environment and climate change can play in influencing the biological characteristics and behaviour of smolts leaving freshwater, and the impact this may have on the subsequent survival of salmon within the marine environment. Three specific factors are considered in detail: smolt size and age, the timing of smolt migrations, and smolt quality. It is based on a review of recent literature, but also draws on exploratory investigations completed as part of the ICES Study Group on Biological Characteristics as Predictors of Salmon Abundance (ICES, 2009, 2010), as well as other data available to the authors and which have been integrated into the review.

\section{Smolt size and age Background}

Smoltification is the process by which juvenile salmon become adapted for downstream migration, seawater entry, and marine residence. For smolting to occur, a critical size (or size-related development stage) is necessary (McCormick et al., 1998), and conditions in freshwater such as temperature, food availability, photoperiod, and competition affect the attainment of this size/ stage. Hence, environmental factors affect smolt age, and fast-growing populations smoltify at younger ages (Swansburg et al., 2002). Over the geographic range, there is a significant negative correlation between the mean age of smoltification and an index of growth potential based on degree-days and photoperiod length (Metcalfe and Thorpe, 1990). Smolts are typically slowergrowing and older at more northerly latitudes. Once the critical developmental stage has been reached, photoperiod and to a lesser extent temperature regulate physiological changes in the smolts in spring, which, in turn, allow downstream migration to be initiated by factors such as temperature, flow, and turbidity (McCormick et al., 1998).

Smolt size varies among populations. Klemetsen et al. (2003) noted that large smolts (mean length typically $>20 \mathrm{~cm}$ ) tend to derive from northern rivers that enter a cold ocean, such as rivers in parts of Quebec, whereas small smolts (averaging $12-13 \mathrm{~cm}$ ) often arise from cold rivers flowing into a relatively warm ocean, such as glacier-fed rivers along the west coast of Norway. However, individual river, or even tributary, characteristics, and year-to-year fluctuations, may play as large a part in determining smolt size as any such broad geographic factors. For example, Jutila et al. (2006) reported a significant negative correlation between annual mean smolt size and the density of wild $>1$-year-old parr during the previous autumn in a northern Baltic river. In Newfoundland, a positive relationship has also been reported between mean smolt size and the proportion of lacustrine habitat (Klemetsen et al., 2003).

Økland et al. (1993) indicated that within populations, smolt age and size depended on growth rate, with fast-growing parr smolting younger and smaller than slow-growing parr. Therefore, smolt size typically increases with age. Assuming that food was not limiting, parr would be expected to grow faster (and hence probably smolt at a younger age) with increasing temperature, up to an optimal temperature for growth of $\sim 16^{\circ} \mathrm{C}$ (Elliott and Hurley, 1997). However, although climate-driven temperature changes are likely to play a major part in regulating smolt size and age, density-dependent mortality and factors that affect juvenile salmonid density may be more important (Gurney et al., 2008; Bal et al., 2011).

\section{Evidence for change}

Analysis of mean smolt ages for 31 wild salmon stocks throughout the geographic range of the species indicated a significant decline over the period 1989-2009 for 55\% of the datasets, with only three stocks showing a significantly increasing trend (ICES, 2009). As that analysis was based on smolt ages derived from adult fish that had survived to return to freshwater, it might not accurately 
reflect the age composition of smolt cohorts if different age/size classes of smolts have different survival rates in the sea. For some stocks at least, this may not be a concern. Comparison of smolt age data for migrating smolts and returning adults from the River North Esk (Scotland) indicated no evidence of differential mortality among smolt ages (ICES, 2010; Todd et al., Pers. Comm.).

To assess the trends further, these dataseries were grouped according to the standard stock-complex areas used by ICES in providing management advice: NASCO's North American (NAC) and North-East Atlantic Commission (NEAC) areas, with the latter being subdivided into northern (NNEAC) and southern (SNEAC) areas (ICES, 2011). The NAC area consists of the United States and Canada, the NNEAC area Finland, Norway, Russia, Sweden, and North/East Iceland, and the SNEAC area Ireland, France, UK (Scotland), UK (England and Wales), UK (Northern Ireland), and South/West Iceland. The trends over time, since 1960 , of standardized mean smolt age ( $z$-scores) for each area were modelled using generalized additive models (GAMs) using the R (R Development Core Team, 2010) package "mgcv" (Wood, 2006). The smoothing functions were fitted by thin-plate regression splines, and the extent of smoothing was determined by generalized cross validation (Wood, 2006).

The smoothed effect of year is statistically highly significant for all three management areas (all values of $p<0.001$; Figure 1). Mean smolt age in the NAC rivers declined in the early part of the series to a stable level from 1990. In the NNEAC rivers, there was an increase in mean smolt age until about 1997, following which there has been a marked decline. In contrast, the SNEAC group has shown fluctuations within an overall linear decline throughout the observation period. The reasons for these apparent regional differences are not clear, but the NNEAC and SNEAC responses lend weight to the case for managing them as distinct stock complexes. The persistent decline in the SNEAC area is perhaps consistent with climate effects being more evident at the southern edge of the species' range, although the caveat remains that age at smoltification is likely influenced by the interactive effects of multiple (perhaps interdependent) environmental influences.

Changes in freshwater growth and smolt age in recent decades have been reported by a number of authors. These mainly indicate significant increases in the size of salmon parr and declines in mean smolt age concurrent with temperature increases (Baglinière et al., 2004; Davidson and Hazlewood, 2005; Jonsson et al., 2005; Aprahamian et al., 2008; ICES, 2009, 2010). However, mean annual size-at-age of juvenile salmon decreased in the northwest and southwest Miramichi Rivers in eastern Canada between 1971 and 1999, and parr size was negatively correlated with spring temperatures (Swansburg et al., 2002). The latter concluded that the relationship between size-at-age and temperature is more complex than laboratory experiments indicate. For example, density-dependent effects and prey availability, itself perhaps influenced by freshwater temperatures, will likely also play a part.

\section{Causes of change}

Declines in mean smolt age are generally regarded as being a consequence of an increased growth rate, because the faster-growing parr migrate to sea earlier (Metcalfe et al., 1989; Økland et al., 1993). The increase in the growth rate may relate to an increase in temperature (Metcalfe and Thorpe, 1990; Jonsson et al., 2005), and/or an increase in growth as a result of density-dependent
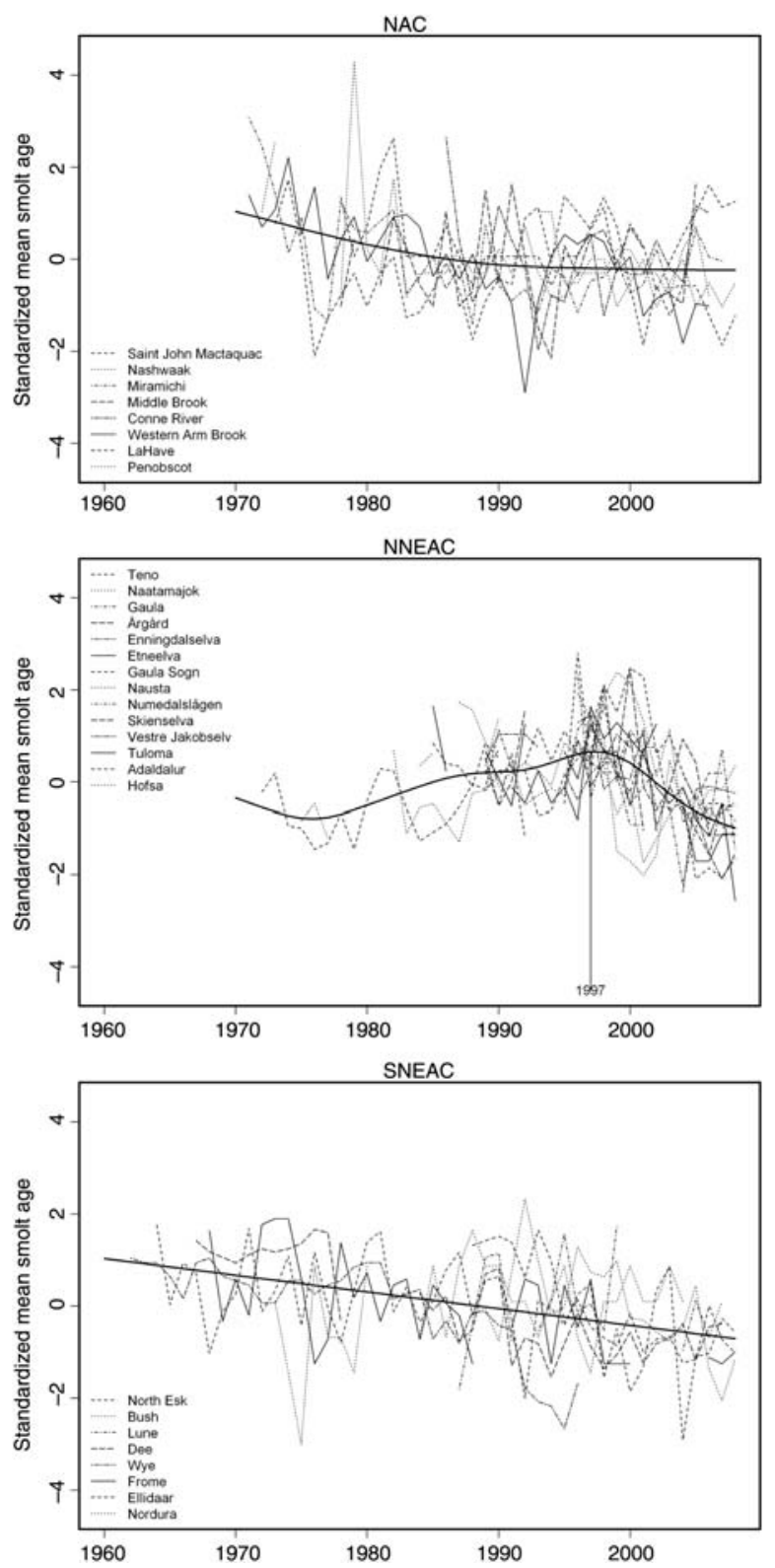

Figure 1. Trends in standardized mean smolt ages for various rivers in NASCO's NAC, SNEAC, and NNEAC areas (see text for country details), 1960-2008. Standardized mean values (z-scores) were derived by subtracting the river mean (1960-2008) and dividing by the s.d. (1960-2008). The trend lines were fitted using GAMs. The smoothed effect of year is statistically highly significant for all three management areas (all $p$-values $<0.001$ ).

processes (Gibson, 1993; Jenkins et al., 1999; Imre et al., 2005; Lobón-Cerviá, 2005; Jutila et al., 2006; Gurney et al., 2008; Bal et al., 2011), and/or increased freshwater production (Aprahamian et al., 2008). Other climatic factors have also been reported to affect growth and smolt age. For example, Jonsson et al. (2005) reported a positive correlation between the growth rate of parr in their first year and river temperature, river flow, and the North Atlantic Oscillation Index during winter of egg incubation and also a positive correlation between river temperature and the proportion of salmon migrating to sea as 1-year-old smolts. It is apparent, therefore, that the hydrological and 
thermal regime of the nursery river, in addition to latitude, elevation, prey availability, and density of competing salmonids, will all influence parr growth and age at smoltification. Although temperature may be the primary determinant of systematic shifts in smolt age, this is not exclusive of other environmental influences (Todd et al., 2011).

Growth in salmonids is regulated by temperature. Brett (1979) suggested that growth typically increases linearly with water temperature up to an optimum rate, given an adequate food supply. Juvenile salmon grow fast over a wide temperature range $\left(10-18^{\circ} \mathrm{C}\right.$; Handeland et al., 2008), but the temperature growth function is strongly peaked (Elliott and Hurley, 1997). Therefore, growth declines as temperature increases above the optimum, and the optimum is also affected by interaction with prey availability. The effect that predicted temperature increases might have on age and growth of smolts is, therefore, expected to be complex and variable (Swansburg et al., 2002). Davidson and Hazlewood (2005) used forecasts of temperature regimes to the end of this century under different emission scenarios (UKCIP, 2002) to predict the growth rates of salmon in freshwater based on the model of Elliott and Hurley (1997). This prediction indicated that for rivers in the southwest and north of England, freshwater growth rates could generally improve under the "low emissions" scenario, but may fall below current levels under the "high-emissions" scenario as temperatures exceed optimum levels in the latter half of the century. Swansburg et al. (2002) suggested that predicted increases in air and water temperatures may adversely affect juvenile salmon and reduce overall productivity.

\section{Implications of the changes for marine survival}

Younger smolts are typically smaller than older smolts (Økland et al., 1993). Therefore, the recent trend in many stocks for faster growth and lower mean smolt age is expected to result in a larger proportion of smaller smolts migrating to sea. As mortality at sea is generally thought to be growth-mediated, particularly by factors acting during the first summer (Friedland et al., 2009), it is likely that smaller smolts might experience greater losses. Predation is probably the most important source of mortality when salmon leave freshwater (Hansen et al., 2003) because small fish are vulnerable to a broader range of predators than large fish, predators may aggregate around estuaries during the smolt run (e.g. Greenstreet et al., 1993), and more predators are thought to occur inside the continental shelf than in oceanic areas (Hansen et al., 2003). A review of recent tracking studies (E. Thorstad, pers. comm.) has indicated that the natural mortality of smolts is typically greater in estuaries and close to river mouths than in the river or in the early marine phase (up to $\sim 200 \mathrm{~km}$ from river mouths), with predation the main factor.

There is extensive evidence for size being an important factor determining the marine survival of hatchery-reared smolts, with mortality being lower for larger smolts (e.g. Lundqvist et al., 1994; Kallio-Nyberg et al., 2004; Lacroix and Knox, 2005). Wild smolts survive better at sea than their hatchery counterparts (e.g. Kallio-Nyberg et al., 2004, 2006), but releasing hatchery fish as parr to produce semi-wild smolts may moderate this difference (Jokikokko et al., 2006). The role of smolt size in influencing the survival of wild stocks has been less well studied, and evidence remains equivocal. For example, for wild fish from River North Esk (Scotland), smolt size had no apparent influence on the resultant survival rate to adulthood (Friedland et al., 2009; ICES, 2010), whereas for other stocks, the adult survival rate has been correlated with size-at-sea entry (Jokikokko et al., 2006; Friedland et al., 2009; Antonsson et al., 2010).

There is conflicting evidence as to whether Atlantic salmon smolt size influences subsequent post-smolt growth at sea. Both negative (Skilbrei, 1989; Nicieza and Braña, 1993; Jonsson and Jonsson, 2007) and positive relationships (Lundqvist et al., 1988; Salminen, 1997) have been reported, and Friedland et al. (2006) demonstrated that marine growth of post-smolts in the Gulf of St Lawrence from August to October was independent of freshwater growth history. Jonsson and Jonsson (2007) explored a number of hypotheses that might explain why larger smolts could experience slower growth at sea, including the suggestion that smaller smolts may be better adapted to the marine environment (Einum et al., 2002).

There is also conflicting evidence as to the role played by the freshwater environment in determining the sea age of returning adult salmon. Several studies have found that the duration of the marine phase is inversely related to smolt size (Nicieza and Braña, 1993; Erkinaro et al., 1997). However, in other stocks, it is evident that fish that develop quickly in freshwater continue to do so once they migrate to sea (Anon, 1994). A number of authors has concluded that there is no fundamental causal mechanism linking freshwater growth and sea age (Gardner, 1976; Bielak and Power, 1986; Anon, 1994). Provisional results for the Rivers Frome (England) and Dee (Wales) suggest that the sex of fish may influence the strength of the relationship between smolt size and age at maturity (ICES, 2009).

A possible consequence of the higher growth rates in freshwater and younger age at migration of smolts is damping of the impact of increased marine mortality. This assumes that the shorter time spent in freshwater, and the expected greater survival to smolting, is not outweighed by higher marine mortality as a result of migrating to sea at a smaller size. Shortening of the generation time increases an individual's chance of surviving to breed, but may represent something of a trade-off, because early maturing individuals are commonly smaller and produce fewer and/or smaller progeny. Hence, an optimal trade-off will depend on age-specific rates of growth and mortality (Stearns, 1992), and Roff (1992) suggested that a trait will change in relation to changes in age-specific mortality, growth, and fecundity to ensure that fitness is maximized.

\section{Run-timing \\ Background}

Smolt run-timing can be measured in different ways, including onset or duration of migration, or the timing of marine entry. In practice, most information on run-timing is derived from traps located in the lower reaches of rivers, so data typically relate to smolt capture at that point. Changing daylength has been suggested as the ultimate trigger to smolt migration, with river conditions such as temperature, discharge, and turbidity serving as proximate triggers controlling the smolt run in different rivers (McCormick et al., 1998; Jutila et al., 2005; Riley, 2007; Todd et al., 2011). Therefore, the timing of smolt migration varies with latitude, with smolts from southern rivers going to sea earlier than smolts from more northerly rivers (Figure 2). Run-timing is also much later in rivers bordering the Northwest Atlantic than in those at comparable latitudes in the Northeast Atlantic, and this difference increases slightly with latitude (Figure 2). Migration timing is also correlated with body size, with larger/older, slower- 


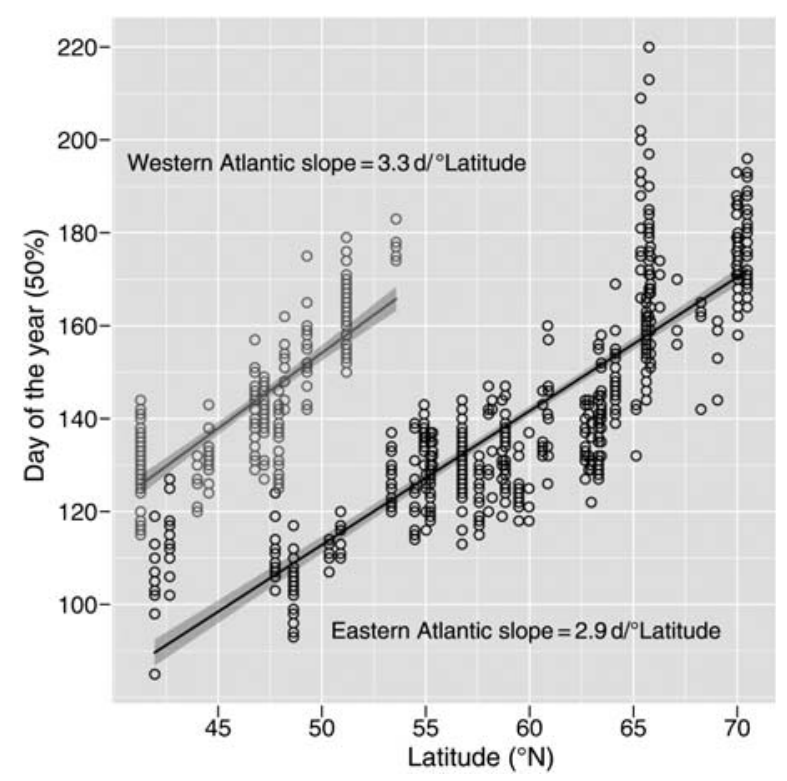

Figure 2. Day of the year of $50 \%$ cumulative downstream smolt migration as a function of latitude and sampling area for 62 monitored rivers in the western and eastern North Atlantic. An analysis of covariance model was fitted to the data, but there was no significant difference between slopes. The figure has been updated from Otero et al. (2010) through the addition of several new river datasets.

growing smolts within a river typically migrating earlier (Jutila and Jokikokko, 2008; Kennedy and Crozier, 2010), and this may have a genetic component (Stewart et al., 2006).

The timing of smolt migration is crucial to the survival of Atlantic salmon at sea (Hansen, 1987; Hvidsten et al., 1998), and it is regarded as an adaptation to the prevailing environmental conditions in an area. The timing of release also influences marine survival in hatchery-reared smolts (Kallio-Nyberg et al., 2009). Possible changes in the run-timing of smolts as a result of variations in climate are, therefore, a concern because of the possible temporal mismatch with optimal conditions for early postsmolt growth and survival. McCormick et al. (1998) suggested that there may be two interacting aspects of migration timing that affect smolt survival: a physiological window controlled by photoperiod, temperature, and flow, which determines the readiness of smolts for migration and seawater entry, and an environmental window, when conditions in the river, estuary, and coastal environment are most suitable for survival. McCormick et al. (1998) indicated that when migration timing and optimum environmental conditions coincide, adult returns are high, and vice versa. Evidence for an optimum smolt window is provided by the results of various studies (e.g. Hansen, 1987; Hansen and Jonsson, 1989; McCormick et al., 1999; Crozier et al., 2003; Dempson et al., 2003; Hvidsten et al., 2009; Antonsson et al., 2010), although relationships between runtiming and sea survival may not be consistent among all rivers in an area (Crozier et al., 2003).

\section{Evidence for change}

Recent studies have indicated that smolt run-timing is becoming earlier (ICES, 2010). In the River Bush (Northern Ireland), for example, run-timing in recent years has been around 2 weeks

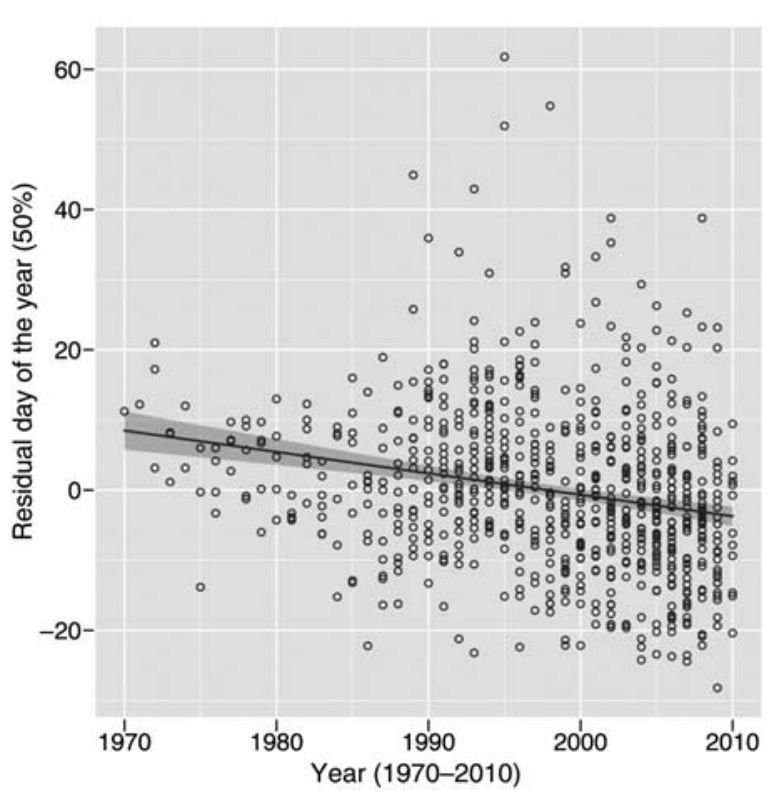

Figure 3. Time-trend since the early 1970 s of the date of $50 \%$ cumulative downstream smolt migration for 62 monitored rivers in the western and eastern North Atlantic. Note that the $y$-axis shows the day of the year accounting for the geographic effects modelled in Figure 2, i.e. the values represent the residuals of the analysis of covariance where negative (positive) values indicate earlier (later) downstream migration than predicted for a given geographic location. The figure has been updated from Otero et al. (2010) through the addition of several new river datasets and the inclusion of the day-of-the-year standardization described above.

earlier than in the late 1970s (Kennedy and Crozier, 2010). A broader examination of run-timing since the 1970s for 62 salmon stocks across the range of the species suggests an overall trend of run-timing (measured as the date of $50 \%$ cumulative smolt descent) being earlier at an average rate of almost $3 \mathrm{~d}$ per decade (Figure 3).

\section{Causes of change}

Given that daylength, considered the ultimate trigger for smolt migration, varies according to a consistent annual pattern, the factors driving earlier migration are likely linked to climate change and warming temperatures in particular. The observed changes in runtiming have coincided with general increases in river and coastal temperatures in spring (e.g. Davidson et al., 2006; ICES, 2010; Kennedy and Crozier, 2010). As smolt migration is cued by water temperatures and temperature increases over land, and hence freshwater, are expected to exceed those over the surface of the oceans (IPCC, 2007), mismatches relative to marine conditions might result and affect survival.

Higher spring temperatures will both enhance the physiological readiness of smolts and act as an early proximate trigger for their migration (McCormick et al., 1998). However, McCormick et al. (2009) noted that smolt development is reversible and that the period of peak physiological readiness in smolts is limited by time and temperature, such that an increase in temperature is likely to decrease the width of the physiological smolt window. Changes in other proximate smolt-run triggers, such as river discharge and turbidity, are also likely to affect run-timing, because 
changes in the patterns of precipitation and snow melt are predicted consequences of climate change (IPCC, 2007).

\section{Implications of the changes for marine survival}

The timing of seawater entry is believed to have evolved such that smolts enter the sea in synchrony with optimal biotic and abiotic conditions (Hvidsten et al., 1998). For example, Hvidsten et al. (2009) demonstrated a significant positive correlation between both sea temperature and food availability at the time of smolt entry and subsequent adult return rates. When smolts enter saltwater, their energy expenditure increases, and scarce food resources then may result in increased mortality. Studies have demonstrated that high levels of smolt mortality are common in estuaries and marine areas close to river mouths (Lacroix, 2008; Serrano et al., 2009; Thorstad et al., 2011), with predation a major contributory factor (Dieperink et al., 2002; Thorstad et al., 2011). Vulnerability to predation may also increase during the acclimation of smolts to saltwater (Handeland et al., 1996). Potential mismatches in the timing of migration may therefore have a number of consequences for smolts.

Temperature is likely to be a key determinant of the performance of smolts during the early stages of the marine phase, affecting their growth, survival, and behaviour. Temperature can act on growth directly by affecting physiological processes or indirectly by modifying ecosystems (e.g. food availability or changes in other aspects of the rearing environment). Friedland (1998) demonstrated a link between the survival patterns of two European stocks in Scotland and Norway and the thermal regimes experienced by post-smolts during their first weeks at sea, with better survival typically linked to warmer sea surface temperature. Further, Hvidsten et al. (1998) demonstrated consistent temperatures $\left(\sim 8^{\circ} \mathrm{C}\right)$ at seawater entry for smolts from five rivers throughout Norway, despite marked differences in the timing of the smolt runs and the temperatures in these rivers. This synchronicity may reflect food availability, but osmotic stress on entering seawater is also reported to be more severe for smolts at temperatures $<6-$ $7^{\circ} \mathrm{C}$ (Sigholt and Finstad, 1990; Handeland et al., 2000).

Increased temperature differentials between freshwater and seawater may also impact smolts directly. Staurnes et al. (2001) demonstrated that smolts transferred to seawater in which the temperature gradient was $>4-6^{\circ} \mathrm{C}$ had poorer seawater challenge performance. Friedland et al. (2003) suggested that strong migrational behaviours that select for particular preferred temperature ranges could impose significant energetic costs on post-smolts as they seek optimal ocean-surface temperatures.

Kennedy and Crozier (2010) suggested a link between the runtiming of smolts and the survival of returning one-sea-winter salmon on the River Bush since the 1980s (Figure 4). This coincided with a marked increase in the temperature difference between the river and the sea at the time of the smolt migration. It was suggested that the shift towards earlier smolt emigration may have resulted in a temporal mismatch with the local spring plankton bloom, with consequent reduction in early marine feeding opportunities and survival. The inference was that climatedriven processes were forcing early running smolts outside the preferential environmental smolt window. Given the potential for a high degree of congruence in smolt run-timing in particular areas (e.g. Dempson et al., 2003), such impacts might be expected to be manifest over wider areas. The River Bush case study may, however, be subject to particular local geographic conditions, because the river lacks a defined estuary and discharges directly

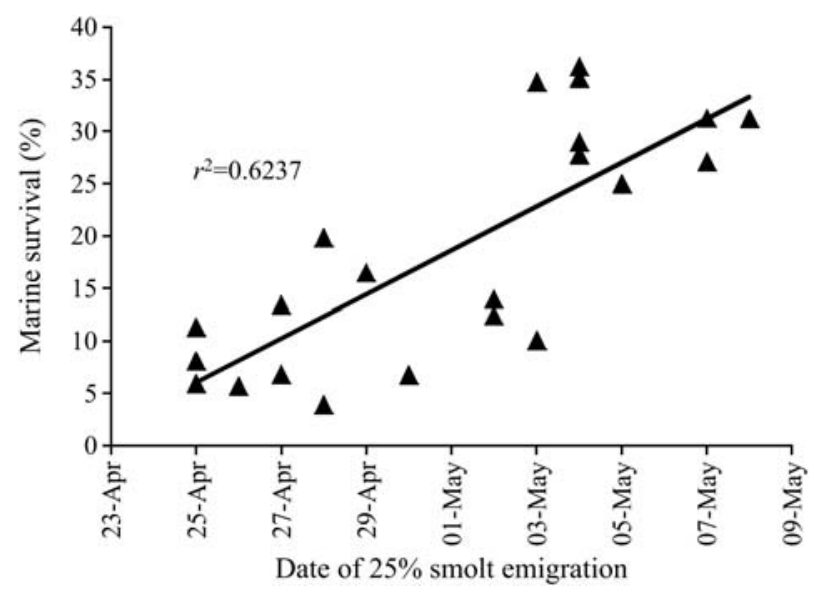

Figure 4. Relationship between the ordinal date of smolt run onset (25\% of smolt emigration) and subsequent marine survival of one-sea-winter River Bush salmon back to the coast, for smolt years 1986-2009. The figure has been updated from that which appeared in Kennedy and Crozier (2010) through the addition of two further years of data. This enhanced the significant positive linear relationship $\left(r^{2}=0.6237, n=22, p<0.001\right)$.

into the North Atlantic, potentially intensifying the effects of any freshwater/marine temperature gradient (RJK, pers. obs.). Preliminary temperature analyses for four other UK rivers (ICES, 2010) suggest modest warming of rivers and coastal waters over the past 10-20 years, particularly for the two most southerly rivers. However, there was little evidence of a thermal mismatch between spring river and sea temperatures in any of these rivers over the past $40+$ years.

\section{Smolt quality Background}

Both the number of spawning adults and the capacity of the freshwater environment to sustain fish through their juvenile freshwater stages will be critical in determining the number of smolts entering the sea from any river. Adequate smolt numbers are clearly essential to population viability. However, the fitness of smolts as they enter the marine environment will also be important in determining their subsequent performance in the sea. Life-history traits associated with smoltification are reported to be genetically determined and population-specific, with differences having potential consequences for smolt quality and marine survival (McGinnity et al., 2007). In addition, environmental conditions in freshwater can affect the physiology and energy reserves of smolts and have possible far-reaching consequences for subsequent performance at sea and for the long-term sustainability of populations (McCormick et al., 2009).

\section{Evidence for change}

Habitat availability, feeding opportunities, and modifications to the thermal and flow regimes of rivers may all influence juvenile salmon in freshwater and be reflected in smolt quality. Certain smolt-quality criteria affect marine survival in hatchery-reared fish in the Baltic (ICES, 2009, 2010). Comparative data for wild smolts are sparse, although there is some evidence to suggest that plumper smolts survive better (Antonsson et al., 2010). In that study, however, the effect of smolt condition on survival to 
adults was less evident than the effects of size (length) and age. However, there is growing evidence that other environmental factors acting on fish in freshwater also affect smolts once they enter the marine environment (McCormick et al., 2009). Exposure to various environmental contaminants influences the osmoregulatory function and restricts the ability of smolts to adapt physiologically to saline conditions. They include pesticides (Fairchild et al., 2002; Moore et al., 2003, 2007, 2008; Waring and Moore, 2004), acid water and aluminium (Magee et al., 2001; Kroglund et al., 2007), oestrogenic compounds (Fairchild et al., 1999), brominated flame retardants (Lower and Moore, 2007), and suspended sediments (Shrimpton et al., 2007). For example, the exposure of juvenile Atlantic salmon to the widely used pesticide atrazine during the parr-smolt transformation reduces gill $\mathrm{Na}^{+} \mathrm{K}^{+}$ATPase activity, reduces the ability to adapt to salt water, and increases the mortality of smolts on exposure to full-strength seawater (Moore et al., 2003; Waring and Moore, 2004).

In addition, contaminants inhibit migratory behaviour and modify the olfactory sensitivity of smolts to key odorants considered to be important when imprinting to the home river (Lower and Moore, 2007; Moore et al., 2007). In juvenile Chinook salmon (Oncorhynchus tshawytscha), short-term exposure to pesticides, at levels representative of seasonal pesticide use, may also reduce growth and size at sea entry (Baldwin et al., 2009).

McCormick et al. (2009) reviewed the impact of a range of perturbations acting in the freshwater environment, including temperature, dams, and contaminants, and concluded that those factors can affect smolt physiological development, post-smolt behaviour, early seawater survival, growth, and homing. However, the effects of increasing temperature on chemical toxicity may be complex and influenced by toxicant-specific metabolic processes (Kennedy and Walsh, 1997).

\section{Causes of change}

As noted previously, climate change is expected to be a key driver for change and will impact on hydrology and water resources in a variety of ways (IPCC, 2007), with wide-ranging implications for river flows and Atlantic salmon populations (Walsh and Kilsby, 2007; Clews et al., 2010). Higher water temperatures and variations in run-off are also expected to contribute to adverse changes in water quality (IPCC, 2007), and they will exacerbate the impact of environmental contaminants. General deterioration in water quality is anticipated as a consequence of warming, because higher temperatures affect the self-purification capacity of rivers by reducing the amount of oxygen that can dissolve and function in biodegradation. Higher run-off also increases the biological mobilization of fertilizers and pesticides, erosion, and the input of other pollutants (through overloading of wastewater treatment plants, storm water drains, etc.). Acidification of rivers and lakes is also expected to increase as a result of higher levels of acidic atmospheric deposition.

In addition to these climate-driven changes, it is anticipated that there will be increasing demands for water abstraction to meet the needs of industry, agriculture, aquaculture, and domestic use. These in turn will continue to give rise to point-source and diffuse pollution and result in a wide range of contaminants in the environment. Taken together, freshwater ecosystems are likely to be subject to increasing pressures, with potentially wideranging consequences for salmon and other aquatic species.

\section{Implications of the changes for marine survival}

It is clearly vital that as well as entering the sea at the right time, smolts enter the sea in good condition if they are to meet the challenges posed by this novel environment and survive to return as adults, i.e. that the physiological and environmental smolt windows are synchronized as far as possible (McCormick et al., 1998). Focused research on the impact that freshwater perturbations might have on marine survival is in its relative infancy. However, it is already apparent that even subtle, sublethal effects at key developmental stages may have marked effects on subsequent life stages, with potential implications both for adult returns and the long-term sustainability of populations (Baldwin et al., 2009; McCormick et al., 2009).

Factors that affect smolt development and salinity tolerance may compromise growth, swimming performance, and metabolism (the physiological window), with implications for migration, predator avoidance, disease resistance, competitive ability, and hence survival. Those which cause a delay in migration have the potential to alter run-timing, with a consequent failure to temporally match the environmental window. Moreover, factors that affect the olfactory abilities of individual fish may compromise their ability to imprint and migrate back to their natal river. In turn, all these impacts have the potential to affect the subsequent survival of fish in the marine environment and the long-term productivity of populations. Based on available evidence, McCormick et al. (2009) concluded that the reduced levels of marine survival observed throughout the North Atlantic already, in part, reflect the influence of anthropogenic influences acting in freshwater, i.e. in effect, that smolts "take it with them when they go".

\section{Future research needs and implications for management}

The foregoing highlights the critical role that the freshwater environment plays in the life cycle of Atlantic salmon, and it reinforces the view that the freshwater, estuarine, and marine phases cannot be considered in isolation. What transpires in freshwater plays a key part in determining the performance and survival of salmon during their subsequent life stages. It is also clear that climate change, in concert with other anthropogenic pressures on the freshwater environment, will continue to pose substantial challenges both for the fish and those who seek to manage them. Factors operating in the marine environment undoubtedly play a pivotal part in determining the productivity of salmon populations, but with the exception of fisheries and inshore activities such as aquaculture, these are essentially outside the control of managers. In contrast, freshwater factors clearly also have a substantial influence on salmon productivity and freshwater habitats are more amenable to management. Hence, understanding how factors operating in freshwater impact stocks is vital to managers and should not be overlooked in the face of ongoing pressures to understand the factors regulating salmon at sea better. Maximizing the smolt output should also be a clear objective for managers because it will help offset the effect of increased mortalities at sea (Todd et al., 2011).

Each of the issues reviewed in this paper (smolt size/age, runtiming, and smolt quality) suggest patterns of substantial recent change. Managers need to recognize the essential importance of long-term monitoring programmes of salmon juveniles and emigrant smolts as indicators of change, and for assessing biological 
responses to environmental variables. Further, it is imperative that work continues to better understand the implications of these changes, both at the individual and the population level, and in the light of predicted climate change scenarios.

The effect of changes in juvenile salmon growth and smolt size/ age on subsequent marine survival is equivocal. For some stocks, the size at ocean entry appears to be correlated with post-smolt growth, with indications that the combined effect of freshwater and post-smolt growth regulates recruitment (Friedland et al., 2009). However, for other stocks, there is no apparent link between smolt size and recruitment. Further efforts are required to collect data on smolt size and to explore links with adult recruitment.

Further work is also required to investigate emigrant smolt runtiming and the evidence for the mismatch between the physiological and environmental smolt windows as a consequence of climate change, and increasing temperature differentials between freshwater and coastal seas. Management action to reduce freshwater temperature increases might be required, e.g. by reducing abstraction and enhancing riparian shading.

Research on the effect of contaminants on salmon survival is in its relative infancy. Key priorities in the future will be to understand better the impacts that different contaminants have on survival and to assess how climate change, and other stressors acting in combination (e.g. Finstad et al., 2007, 2011), may affect such impacts. Recent studies have often focused on short-term impacts, but the period between exposure in freshwater and ocean entry may be critical in terms of whether migration and survival in the sea are compromised (Moore et al., 2008). Therefore, contaminants that affect smolts immediately prior to seawater entry, or that are found in estuaries, may be of particular concern. Modelling approaches are also needed to allow the effects on individuals to be extrapolated to the population level. Effective management of freshwater resources is likely to become increasingly challenging in the light of predicted changes in the climate and as other pressures increase. In light of these challenges, a comprehensive evidence base will be essential in order to safeguard the needs of salmon and other aquatic species of similar cultural, socio-economic, and ecological importance.

\section{Acknowledgements}

We acknowledge with thanks the contributions of all those scientists who contributed data on smolt migrations to the ICES Study Group on Biological Characteristics as Predictors of Salmon Abundance (ICES, 2009, 2010) and in support of other analyses reported in this paper.

\section{References}

Anon. 1994. Run timing of salmon. Report of the Salmon Advisory Committee. MAFF, London. 55 pp.

Antonsson, T., Heidarsson, T., and Snorrason, S. S. 2010. Smolt emigration and survival to adulthood in two Icelandic stocks of Atlantic salmon. Transactions of the American Fisheries Society, 139: $1688-1698$.

Aprahamian, M. W., Davidson, I. C., and Cove, R. J. 2008. Life history changes in Atlantic salmon from the River Dee, Wales. Hydrobiologia, 602: 61-78.

Baglinière, J. L., Denais, L., Rivot, E., Porcher, J. P., Prévost, E., Marchland, F., and Vauclin, V. 2004. Length and age structure modifications of the Atlantic salmon (Salmo salar) populations of Brittany and Lower Normandy from 1972 to 2002. Technical
Report, Institut National de la Recherche Agronomique and Conseil Superieur de la Peche, Rennes. 24 pp.

Bal, G., Rivot, E., Prévost, E., Piou, C., and Baglinière, J. L. 2011. Effect of water temperature and density of juvenile salmonids on growth of young-of-the-year Atlantic salmon Salmo salar. Journal of Fish Biology, 78: 1002-1022.

Baldwin, D. H., Spromberg, J. A., Collier, T. K., and Scholz, N. L. 2009. A fish of many scales: extrapolating sublethal pesticide exposures to the productivity of wild salmon populations. Ecological Applications, 19: 2004-2015.

Bates, B. C., Kundzewicz, Z. W., Wu, S., Arnell, N., Burkett, V., Döll, P., Gwary, D., et al. 2008. Climate Change and Water. Technical Paper of the Intergovernmental Panel on Climate Change. IPCC Secretariat, Geneva, IPCC-XXVIII/Doc.13. 244 pp.

Bielak, A. T., and Power, G. 1986. Independence of sea-age and riverage in Atlantic salmon (Salmo salar) from Quebec North Shore Rivers. In Salmonid Age at Maturity, pp. 70-78. Ed. by D. J. Meerburg. Canadian Special Publication in Fisheries and Aquatic Sciences, $89.188 \mathrm{pp}$.

Brett, J. R. 1979. Environmental factors and growth. In Fish Physiology, 8, pp. 599-675. Ed. by W. S. Hoar, D. J. Randall, and J. R. Brett. Academic Press, London. 803 pp.

Clews, E., Durance, I., Vaughan, I. P., and Ormerod, S. J. 2010. Juvenile salmonid populations in a temperate river system track synoptic trends in climate. Global Change Biology, 16: 3271-3283.

Crozier, W. W., and Kennedy, G. J. A. 2003. Freshwater influences on marine survival of Atlantic salmon (Salmo salar L.): evidence from the River Bush, Northern Ireland. In Marine Mortality of Atlantic Salmon, Salmo salar L.: Methods and Measures, pp. 124-129. Ed. by E. C. E. Potter, N. O'Maoiléidigh, and G. Chaput. Research Document, Canadian Science Advisory Secretariat 2003/101. 213 pp.

Crozier, W. W., Potter, E. C. E., Prevost, E., Schon, P-J., and O'Maoiléidigh, N. 2003. A co-ordinated approach towards development of a scientific basis for management of wild Atlantic salmon in the North-East Atlantic (SALMODEL). An EU Concerted Action-Quality of Life and Management of Living Resources Key Action 5: Sustainable agriculture, fisheries and forestry, and integrated development of rural areas including mountain areas. Contract No. QLK5-CT1999-01546. $431 \mathrm{pp}$.

Davidson, I. C., and Hazlewood, M. S. 2005. Effects of climate change on salmon fisheries. Science Report W2-047/SR. Environment Agency, Bristol. 52 pp.

Davidson, I. C., Hazlewood, M. S., and Cove, R. J. 2006. Predicted growth of juvenile trout and salmon in four rivers in England and Wales based on past and possible future temperature regimes linked to climate change. In Sea Trout: Biology, Conservation and Management, pp. 401-416. Ed. by G. Harris, and N. Milner. Blackwell Publishing, Oxford. 499 pp.

Dempson, J. B., Mullins, C., Bourgeois, C., O'Connell, M., and Reddin, D. 2003. Perspectives on smolt production and marine survival of Newfoundland Atlantic salmon (Salmo salar) related to smolt size and run timing. In Marine Mortality of Atlantic Salmon, Salmo salar L.: Methods and Measures, pp. 27-30. Ed. by E. C. E. Potter, N. O'Maoiléidigh, and G. Chaput. Research Document, Canadian Science Advisory Secretariat 2003/101. 213 pp.

Dieperink, C., Bak, B. D., Pedersen, L-F., Pedersen, M. I., and Pedersen, S. 2002. Predation on Atlantic salmon and sea trout during their first days as post-smolts. Journal of Fish Biology, 61: $848-852$.

Einum, S., Thorstad, E. B., and Naesje, T. F. 2002. Growth rate correlations across life stages in female Atlantic salmon. Journal of Fish Biology, 60: 780-784.

Elliott, J. M., and Hurley, M. A. 1997. A functional model for maximum growth of Atlantic salmon parr, Salmo salar, from two populations in northwest England. Functional Ecology, 11: 592-603. 
Erkinaro, J., Dempson, J. B., Julkunen, M., and Niemelä, E. 1997. Importance of ontogenetic habitat shifts to juvenile output and life history of Atlantic salmon in a large Subarctic river: an approach based on analysis of scale characteristics. Journal of Fish Biology, 51: 1174-1185.

Fairchild, W. L., Brown, S. B., and Moore, A. 2002. Effects of freshwater contaminants on marine survival in Atlantic salmon. In Joint Meeting on Causes of Marine Mortality of Salmon in the North Pacific and North Atlantic Oceans and the Baltic Sea, pp. 30-32. North Pacific Anadromous Fish Commission Technical Report, 4.98 pp.

Fairchild, W. L., Swansburg, E. O., Arsenault, J. T., and Brown, S. B. 1999. Does an association between pesticide use and subsequent declines in catch of Atlantic salmon (Salmo salar) represent a case of endocrine disruption? Environmental Health Perspectives, 107: 349-357.

Finstad, B., Bjørn, P. A., Todd, C. D., Whoriskey, F., Gargan, P. G., Forde, G., and Revie, C. W. 2011. The effect of sea lice on Atlantic salmon and other salmonid species. In Atlantic Salmon Ecology, pp. 253-276. Ed. by Ø. Aas, S. Einum, A. Klemetsen, and S. Skurdal. Wiley-Blackwell, Oxford. $496 \mathrm{pp}$.

Finstad, B., Kroglund, F., Strand, R., Stefansson, S. O., Bjørn, P. A., Rosseland, B. O., Nilsen, T. O., et al. 2007. Salmon lice or suboptimal water quality-reasons for reduced postsmolt survival? Aquaculture, 273: 374-383.

Friedland, K. D. 1998. Ocean climate influences on critical Atlantic salmon (Salmo salar) life history events. Canadian Journal of Fisheries and Aquatic Sciences, 55 (Suppl. 1): 119-130.

Friedland, K. D., Chaput, G., and Maclean, J. C. 2005. The emerging role of climate in post-smolt growth of Atlantic salmon. ICES Journal of Marine Science, 62: 1338-1349.

Friedland, K. D., Clarke, L. M., Dutil, J-D., and Salminen, M. 2006. The relationship between smolt and postsmolt growth for Atlantic salmon (Salmo salar) in the Gulf of St Lawrence. Fishery Bulletin US, 104: 149-155.

Friedland, K. D., MacLean, J. C., Hansen, L. P., Peyronnet, A. J., Karlsson, L., Reddin, D. G., Ó’Maoiléidigh, N., et al. 2009. The recruitment of Atlantic salmon in Europe. ICES Journal of Marine Science, 66: 289-304.

Friedland, K. D., Reddin, D. G., and Castonguay, M. 2003. Ocean thermal conditions in the post-smolt nursery of North American Atlantic salmon. ICES Journal of Marine Science, 60: 343-355.

Gardner, M. L. 1976. A review of factors which may influence the sea-age and maturation of Atlantic salmon (Salmo salar). Journal of Fish Biology, 9: 289-328.

Gibson, R. J. 1993. The Atlantic salmon in freshwater: spawning, rearing and production. Reviews in Fish Biology and Fisheries, 3: $39-73$.

Greenstreet, S. P. R., Morgan, R. I. G., Barnett, S., and Redhead, P. 1993. Variation in the numbers of shags Phalacrocorax aristotelis and common seals Phoca vitulina near the mouth of an Atlantic salmon Salmo salar river at the time of the smolt run. Journal of Animal Ecology, 62: 565-576.

Gurney, W. S. C., Bacon, P. J., Tyldesley, G., and Youngson, A. F. 2008. Process-based modelling of decadal trends in growth, survival, and smolting of wild salmon (Salmo salar) parr in a Scottish upland stream. Canadian Journal of Fisheries and Aquatic Sciences, 65: $2606-2622$.

Handeland, S., Berge, A., Bjornsson, B. T., Lie, Ø., and Stefansson, S. O. 2000. Seawater adaptation by out-of-season Atlantic salmon (Salmo salar) smolts at different temperatures. Aquaculture, 181: 377-396.

Handeland, S., Järvi, T., Fernö, T., and Stefansson, S. 1996. Osmotic stress, antipredatory behaviour, and mortality of Atlantic salmon (Salmo salar) smolts. Canadian Journal of Fisheries and Aquatic Sciences, 53: 2673-2680.
Handeland, S. O., Imsland, A. K., and Stefansson, S. O. 2008. The effect of temperature and fish size on growth, feed intake, food conversion efficiency and stomach evacuation rate of Atlantic salmon post-smolts. Aquaculture, 283: 36-42.

Hansen, L. P. 1987. Growth, migration and survival of lake-reared juvenile anadromous Atlantic salmon, Salmo salar L. Fauna Norvegica, Series A, 8: 29-34.

Hansen, L. P., Holm, M., Holst, J. C., and Jacobsen, J. A. 2003. The ecology of post-smolts of Atlantic salmon. In Salmon at the Edge, pp. 25-39. Ed. by D. Mills. Blackwell Science, Oxford. 307 pp.

Hansen, L. P., and Jonsson, B. 1989. Salmon ranching experiments in the River Imsa: effect of timing of Atlantic salmon (Salmo salar) smolt migration. Aquaculture, 82: 367-373.

Hansen, L. P., and Quinn, T. P. 1998. The marine phase of Atlantic salmon (Salmo salar) life cycle, with comparison to Pacific salmon. Canadian Journal of Fisheries and Aquatic Sciences, 55 (Suppl. 1): 104-118.

Hvidsten, N. A., Heggberget, T. G., and Jensen, A. J. 1998. Sea water temperatures at Atlantic salmon smolt entrance. Nordic Journal of Freshwater Research, 74: 79-86.

Hvidsten, N. A., Jensen, A. J., Rikardsen, A. H., Finstad, B., Aure, J., Stefanson, S., Fiske, P., et al. 2009. Influence of sea temperature and initial marine feeding on survival of Atlantic salmon Salmo salar post-smolts from the Rivers Orkla and Hals, Norway. Journal of Fish Biology, 74: 1532-1548.

ICES. 2009. Report of the Study Group on Biological Characteristics as Predictors of Salmon Abundance. ICES Document CM 2009/DFC: 02. $119 \mathrm{pp}$.

ICES. 2010. Report of the Study Group on Biological Characteristics as Predictors of Salmon Abundance. ICES Document CM 2010/ SSGEF: $03.158 \mathrm{pp}$.

ICES. 2011. Report of the Working Group on North Atlantic Salmon. ICES Document CM 2011/ACOM: 09. 284 pp.

Imre, I., Grant, J. W. A., and Cunjak, R. A. 2005. Density-dependent growth of young-of-the-year Atlantic salmon Salmo salar in Catamaran Brook, New Brunswick. Journal of Animal Ecology, 74: 508-516.

IPCC. 2007. Climate Change 2007: the Physical Science Basis. Contribution of Working Group I to the Fourth Assessment Report of the Intergovernmental Panel on Climate Change. Ed. by S. Solomon, D. Qin, M. Manning, Z. Chen, M. Marquis, K. B. Averyt, M. Tignor, et al. Cambridge University Press, Cambridge, UK. 996 pp.

Jenkins, T. M., Diehl, S., Kratz, K. W., and Cooper, S. D. 1999. Effects of population density on individual growth of brown trout in streams. Ecology, 80: 941-956.

Jokikokko, E., Kallio-Nyberg, I., Saloniemi, I., and Jutila, E. 2006. The survival of semi-wild, wild and hatchery-reared Atlantic salmon smolts of the Simojoki River in the Baltic Sea. Journal of Fish Biology, 68: 430-442.

Jonsson, B., and Jonsson, N. 2009. A review of the likely effects of climate change on anadromous Atlantic salmon Salmo salar and brown trout Salmo trutta, with particular reference to water temperature and flow. Journal of Fish Biology, 75: 2381-2447.

Jonsson, N., and Jonsson, B. 2004. Size and age at maturity of Atlantic salmon correlate with the North Atlantic Oscillation Index (NAOI). Journal of Fish Biology, 64: 241-247.

Jonsson, N., and Jonsson, B. 2007. Sea growth, smolt age and age at sexual maturation in Atlantic salmon. Journal of Fish Biology, 71: $245-252$.

Jonsson, N., Jonsson, B., and Hansen, L. P. 2005. Does climate during embryonic development influence parr growth and age of seaward migration in Atlantic salmon (Salmo salar)? Canadian Journal of Fisheries and Aquatic Sciences, 62: 2502-2508.

Jutila, E., and Jokikokko, E. 2008. Seasonal differences in smolt traits and post-smolt survival of wild Atlantic salmon, Salmo salar, 
migrating from a northern boreal river. Fisheries Management and Ecology, 15: 1-9.

Jutila, E., Jokikokko, E., and Julkunen, M. 2005. The smolt run and post-smolt survival of Atlantic salmon, Salmo salar L., in relation to early summer water temperatures in the northern Baltic Sea. Ecology of Freshwater Fish, 14: 69-78.

Jutila, E., Jokikokko, E., and Julkunen, M. 2006. Long-term changes in the smolt size and age of Atlantic salmon, Salmo salar L., in a northern Baltic river related to parr density, growth opportunity and post-smolt survival. Ecology of Freshwater Fish, 15: 321-330.

Kallio-Nyberg, I., Jutila, E., Jokikokko, E., and Saloniemi, I. 2006. Survival of reared Atlantic salmon and sea trout in relation to marine conditions of smolt year in the Baltic Sea. Fisheries Research, 80: 295-304.

Kallio-Nyberg, I., Jutila, E., Saloniemi, I., and Jokikokko, E. 2004. Association between environmental factors, smolt size and the survival of wild and reared Atlantic salmon from the Simojoki River in the Baltic Sea. Journal of Fish Biology, 65: 122-134.

Kallio-Nyberg, I., Salminen, M., Saloniemi, I., and Kannala-Fisk, L. 2009. Marine survival of reared Atlantic salmon in the Baltic Sea: the effects of smolt traits and annual factors. Fisheries Research, 96: $289-295$.

Kennedy, C. J., and Walsh, P. J. 1997. Effects of temperature on xenobiotic metabolism. In Global Warming: Implications for Freshwater and Marine Fish, pp. 303-324. Ed. by C. M. Wood, and D. G. McDonald. Cambridge University Press, Cambridge, UK. 425 pp.

Kennedy, R. J., and Crozier, W. W. 2010. Evidence of changing migratory patterns of wild Atlantic salmon (Salmo salar L.) smolts in the River Bush, Northern Ireland, and possible associations with climate change. Journal of Fish Biology, 76: 1786-1805.

Klemetsen, A., Amundsen, P-A., Dempson, J. B., Jonsson, B., Jonsson, N., O'Connell, M. F., and Mortensen, E. 2003. Atlantic salmon Salmo salar L., brown trout Salmo trutta L. and Arctic charr Salvelinus alpinus L.: a review of aspects of their life histories. Ecology of Freshwater Fish, 12: 1-59.

Kroglund, F., Finstad, B., Stefansson, S. O., Nilsen, T. O., Kristensen, T., Rosseland, B. O., Teien, H. C., et al. 2007. Exposure to moderate acid water and aluminium reduces Atlantic salmon post-smolt survival. Aquaculture, 273: 360-373.

Lacroix, G. L. 2008. Influence of origin on migration and survival of Atlantic salmon (Salmo salar) in the Bay of Fundy, Canada. Canadian Journal of Fisheries and Aquatic Sciences, 65: 2063-2079.

Lacroix, G. L., and Knox, D. 2005. Distribution of Atlantic salmon (Salmo salar) postsmolts of different origin in the Bay of Fundy and Gulf of Maine and evaluation of factors affecting migration, growth, and survival. Canadian Journal of Fisheries and Aquatic Sciences, 62: 1363-1376.

Lobón-Cerviá, J. 2005. Spatial and temporal variation in the influence of density dependence on growth of stream-living brown trout (Salmo trutta). Canadian Journal of Fisheries and Aquatic Sciences, 62: 1231-1242.

Lower, N., and Moore, A. 2007. The impact of a brominated flame retardant on smoltification and olfactory function in Atlantic salmon smolts. Marine and Freshwater Behaviour and Physiology, 40: $267-284$

Lundqvist, H., Clarke, W. C., and Johansson, H. 1988. The influence of precocious sexual maturation on survival to adulthood of river stocked Baltic salmon, Salmo salar, smolts. Holarctic Ecology, 11: $60-69$.

Lundqvist, H., McKinnell, S., Fängstam, H., and Berglund, I. 1994. The effects of time, size and sex on recapture rates and yield after river releases of Salmo salar smolts. Aquaculture, 121: 245-257.

Magee, J. A., Haines, T. A., Kocik, J. F., Beland, K. F., and McCormick, S. D. 2001. Effects of acidity and aluminium on the physiology and migratory behaviour of Atlantic salmon smolts in Maine, USA. Water, Air and Soil Pollution, 130: 881-886.

McCormick, S. D., Cunjak, R. A., Dempson, B., O’Dea, M. F., and Carey, J. 1999. Temperature-related loss of smolt characteristics in Atlantic salmon in the wild. Canadian Journal of Fisheries and Aquatic Sciences, 56: 1649-1658.

McCormick, S. D., Hansen, L. P., Quinn, T. P., and Saunders, R. L. 1998. Movement, migration, and smolting of Atlantic salmon (Salmo salar). Canadian Journal of Fisheries and Aquatic Sciences, 55 (Suppl. 1): 77-92.

McCormick, S. D., Lerner, D. T., Monette, M. Y., Nieves-Puigdoller, K., Kelly, J. T., and Björnsson, B. T. 2009. Taking it with you when you go: how perturbations to the freshwater environment, including temperature, dams and contaminants, affect marine survival of salmon. American Fisheries Society Symposium, 69: $195-214$

McGinnity, P., de Eyto, E., Cross, T. F., Coughlan, J., Whelan, K., and Ferguson, A. 2007. Population specific smolt development, migration and maturity schedules in Atlantic salmon in a natural river environment. Aquaculture, 273: 257-268.

Metcalfe, N. B., Huntingford, F. A., Graham, W. D., and Thorpe, J. E. 1989. Early social status and the development of life-history strategies in Atlantic salmon. Proceedings of the Royal Society of London, Series B, 236: 7-19.

Metcalfe, N. B., and Thorpe, J. E. 1990. Determinants of geographic variation in the age of seaward-migrating salmon, Salmo salar. Journal of Animal Ecology, 59: 135-145.

Moore, A., Cotter, D., Rogan, G., Quayle, V., Lower, N., and Privitera, L. 2008. The impact of a pesticide on the physiology and behaviour of hatchery reared salmon smolts during the transition from the freshwater to marine environment. Fisheries Management and Ecology, 15: 339-345.

Moore, A., Lower, N., Mayer, I., and Greenwood, L. 2007. The impact of a pesticide on migratory activity and olfactory function in Atlantic salmon (Salmo salar L.) smolts. Aquaculture, 273: 350-359.

Moore, A., Scott, A. P., Lower, N., Katsiadaki, I., and Greenwood, L. 2003. The effects of 4-nonylphenol and atrazine on Atlantic salmon (Salmo salar L.) smolts. Aquaculture, 222: 253-263.

Naish, K. A., and Hard, J. J. 2008. Bridging the gap between the genotype and the phenotype: linking genetic variation, selection and adaptation in fishes. Fish and Fisheries, 9: 396-422.

Nicieza, A. G., and Braña, F. 1993. Relationships among smolt size, marine growth, and sea-age at maturity of Atlantic salmon (Salmo salar) in northern Spain. Canadian Journal of Fisheries and Aquatic Sciences, 50: 1632-1640.

Økland, F., Jonsson, D., Jensen, A. J., and Hansen, L. P. 1993. Is there a threshold size regulating seaward migration of brown trout and Atlantic salmon? Journal of Fish Biology, 42: 541-550.

Otero, J., Antonsson, T., Armstrong, J., Arnason, F., Arnekliev, J. V., Baglinière, J. L., Caballero, P., et al. 2010. Environmental effects on ocean entry of Atlantic salmon (Salmo salar) smolt across its range of distribution. ICES Document CM 2010/S: 26.

Parrish, D. L., Behnke, R. J., Gephard, S. R., McCormick, S. D., and Reeves, G. H. 1998. Why aren't there more Atlantic salmon (Salmo salar)? Canadian Journal of Fisheries and Aquatic Sciences, 55 (Suppl. 1): 281-287.

Potter, E. C. E., and Crozier, W. W. 2000. A perspective on the marine survival of Atlantic salmon. In The Ocean Life of Atlantic Salmon: Environmental and Biological Factors Influencing Survival, pp. 19-36. Ed. by D. Mills. Fishing News Books. Blackwell Science, Oxford. $228 \mathrm{pp}$.

R Development Core Team. 2010. R: a Language and Environment for Statistical Computing. R Foundation for Statistical Computing, Vienna, Austria. ISBN 3-900051-07-0, http://www.R-project.org. 
Riley, W. D. 2007. Seasonal downstream movements of juvenile Atlantic salmon, Salmo salar L., with evidence of solitary emigration of smolts. Aquaculture, 273: 194-199.

Roff, D. A. 1992. The Evolution of Life Histories: Theory and Analysis. Chapman and Hall, New York. 535 pp.

Salminen, M. 1997. Relationships between smolt size and sea-age at maturity in Atlantic salmon ranched in the Baltic Sea. Journal of Applied Ichthyology, 13: 121-130.

Serrano, I., Rivinoja, P., Karlsson, L., and Larsson, S. 2009. Riverine and early marine survival of stocked salmon smolts, Salmo salar L., descending the Testebo River, Sweden. Fisheries Management and Ecology, 16: 386-394.

Shrimpton, M. J., Zydlewski, J. D., and Heath, J. W. 2007. Effect of daily oscillation in temperature and increased suspended sediment on growth and smolting in juvenile Chinook salmon, Oncorhynchus tshawytscha. Aquaculture, 273: 269-276.

Sigholt, T., and Finstad, B. 1990. Effect of low temperature on seawater tolerance in Atlantic salmon (Salmo salar) smolts. Aquaculture, 84: $167-172$.

Skilbrei, O. T. 1989. Relationship between smolt length and growth and maturation in the sea of individually tagged Atlantic salmon (Salmo salar). Aquaculture, 83: 95-108.

Staurnes, M., Sigholt, T., Asgard, T., and Baeverfjord, G. 2001. Effects of a temperature shift on seawater challenge test performance in Atlantic salmon (Salmo salar) smolts. Aquaculture, 201: 153-159.

Stearns, S. C. 1992. The Evolution of Life Histories. Oxford University Press, Oxford, UK. 262 pp.

Stewart, D. C., Middlemas, S. J., and Youngson, A. F. 2006. Population structuring in Atlantic salmon (Salmo salar): evidence of genetic influence on the timing of smolt migration in sub-catchment stocks. Ecology of Freshwater Fish, 15: 552-558.

Swansburg, E., Chaput, G., Moore, D., Caissie, D., and El-Jabi, N. 2002. Size variability of juvenile Atlantic salmon: links to environmental conditions. Journal of Fish Biology, 61: 661-683.

Thorstad, E. B., Uglem, I., Arechavala-Lopez, P., Økland, F., and Finstad, B. 2011. Low survival of hatchery-released Atlantic salmon smolts during initial river and fjord migration. Boreal Environment Research, 16: 115-120.

Todd, C. D., Friedland, K. D., MacLean, J. C., Hazon, N., and Jensen, A. J. 2011. Getting into hot water? Atlantic salmon responses to climate change in freshwater and marine environments. In Atlantic Salmon Ecology, pp. 409-443. Ed. by Ø. Aas, S. Einum, A. Klemetsen, and S. Skurdal. Wiley-Blackwell Publishing, Oxford. 496 pp.

Todd, C. D., Hughes, S. L., Marshall, C. T., MacLean, J. C., Lonergan, M. E., and Biuw, E. M. 2008. Detrimental effects of recent ocean surface warming on growth condition of Atlantic salmon. Global Change Biology, 14: 958-970.

UKCIP. 2002. Climate change scenarios for the UK: the UKCIP02 Scientific Report. UK Climate Impacts Programme. 124 pp. http:// www.ukcip.org.uk/ukcp09/ukcip02/.

Walsh, C. L., and Kilsby, C. G. 2007. Implications of climate change on flow regime affecting Atlantic salmon. Hydrology and Earth System Sciences, 11: 1127-1143.

Waring, C. P., and Moore, A. 2004. The effect of atrazine on Atlantic salmon smolts in freshwater and after saltwater transfer. Aquatic Toxicology, 66: 93-104.

Wood, S. N. 2006. Generalized Additive Models: an Introduction with R. Chapman and Hall/CRC, London. 391 pp. 